\title{
Teachers' Empowerment, Self-Regulation and being Istiqamahas key features of Job Performance in Non-Formal Education setting
}

\author{
Laksmi Mayesti Wijayanti \\ Post Graduate Program Universitas Pelita Harapan \\ miss_laksmi@yahoo.com \\ Choi Chi Hyun \\ Post Graduate Program Universitas Pelita Harapan \\ bae7042@daum.net \\ Leo Hutagalung \\ Post Graduate Program Universitas Pelita Harapan \\ leohutangalung234@gmail.com
}

\begin{abstract}
Abstrak
Indonesia menyadari perlunya penguatan pendidikan nonformal sebagai salah satu elemen penting dalam meningkatkan indeks pendidikan. Baik pemerintah maupun lembaga swadaya masyarakat telah berpartisipasi aktif dalam mewujudkan pendidikan nonformal yang lebih mudah diakses dan nyaman. Persoalan mendasar adalah kualitas guru dalam pendidikan masih di bawah harapan. Selain itu, pendidikan nonformal menghadapi dilema dalam menciptakan kinerja guru yang optimal karena bersifat nonprofit. Oleh karena itu, makalah ini akan menyelidiki faktor-faktor penentu dari pengaturan unik tersebut. Instrumen penelitian ini adalah skala pemberdayaan psikologis yang digunakan oleh Spreitzer (1995), The Self-Regulation Questionnaire (SRQ) (Brown, Miller, \& Lawendowski, 1999), skala etos kerja Islami (Ali, 1988) dan angket kinerja diri guru. Kuesioner penilaian (TJPSQ) digunakan sebagai ukuran kinerja guru. Hasil penelitian menunjukkan bahwa pemberdayaan dan istiqamah berpengaruh signifikan terhadap prestasi kerja guru, sedangkan regulasi diri tidak berpengaruh signifikan terhadap prestasi kerja.
\end{abstract}

Kata kunci: pemberdayaan, istiqamah, pengaturan diri, pendidikan nonforma

\begin{abstract}
Indonesia have acknowledged the needs to strengthen the non-formal education as an important element in enhancing the education index. Both government and nongovernment organization have participated actively in establishing the non-formal education to be more accessible and convenience. Nevertheless, it is evidenced that they still manage to deliver their jobs adequately. Therefore, this paper will investigate the determining factors of such unique setting. This study's instruments are the psychological empowerment scale used by Spreitzer (1995), The Self-Regulation Questionnaire (SRQ) (Brown, Miller, \&Lawendowski, 1999), Islamic work ethic scaling (Ali, 1988) and the questionnaire teachers' job performance self-rating questionnaire (TJPSQ) were utilized as a measurement of teachers' job performance. The result indicates that empowerment and istiqamah have significantly influenced to teachers' job performance, while self-regulations have no significant effect on Job performance.

Key words: empowerment, istiqamah, self-regulation, non-formal education
\end{abstract}




\section{A. Introduction}

Indonesia as a part of highly populated countries or E-9 countries,consisted of Bangladesh, Brazil, China, Egypt, India, Indonesia, Mexico, Nigeria and Pakistan still have faced a great challenge in tackling global education agenda. The majority of these countries find a major agenda of achieving universal primary education is still in far reach furthermore they all encounter education quality deficit. OnlyMexico and Brazilhave successfully met gender parity in primary and secondary education (Ololube, 2012).

Indonesian education index 2018 released by Human Development Reports demonstrates that in 2017 Indonesia ranked number 7 in ASEAN with score 0,622. The highest score occupied by Singapore with 0,832 , follow by Malaysia $(0,719)$, Brunei Darussalam $(0,704)$. Forth and fifth shared the same score 0,661 are Thailand and the Philippines.

Education is one of the basic human rights. All citizen reserve the rights to education. This include in Indonesian constitutional law (UUD 1945) article 31. Education also become the backbone of the development of human capital. History have confidently demonstrated that the key factor that determine the success of a nation is not based on the natural resources but rather the human resources (Sudarsana, 2016).

Education can be categorised as formal, informal and non-formal education. Formal education identify as an institutional system that represents mandatory education with very specific and measured outcome. The result should represent definitive certification comprises competence and skills (Tabacaru, 2018). Informal education develop outside the classroom, mostly it involves community based organisation, parents, caregiver, family member and embedded in daily life activity (Ololube, 2011). UNESCO defines non-formal education as a structural education that takes place outside an established and organized school system. It also refers to any sustained or standardized educational activity that does not coincide with formal education setting.

"Non-formal education is imperative for the development of human capital economically, socially, politically and technologically" (Ukwuaba, 2015). Non-formal education is believed as the future trends of the human development program and proved significantly in expanding the human and national development in one of the E9 countries, namely Nigeria (Ololube, 2012). The two main goals in education, knowledge and skill are expected to effectively employ in society can equally be taught outside the formal system (Asiyai, 2018).

UndangUndangRepublik Indonesia number 20 in 2003 regarding National Educational System emphasize the definition of Non-formal education. Article (1) non formal education is an educational path outside the system of formal education and can directly implemented with structured and tiered. Furthermore in article (2) non formal education organized for citizen who need educational service as an enhancer and complimentary of formal education in order to support lifelong learning 
Non-Formal education has encountered dilemma in creating optimum performance of their teacher due to its non-profit nature. Nevertheless, it is evidenced that they still manage to deliver their jobs adequately. Therefore, this paper will investigate the determining factors of such unique setting.

\section{Literature Review Teacher Empowerment}

Empowerment has been a focus of numerous research. Arsalan \& Zaman (2014) argued that "empowerment plays a crucial role in boosting employees' performance". Furthermore, they identified empowerment as the way to improve the ability of a group and individuals to make different decision to change into expected act and result.

Degago 2014 stated in his research that employee empowerment is the key factor of the employee performance particularly in the era of globalization whereas institution need to respond quickly and adaptive with different changes in the environment. The proposed intervention are namely to respect and to help employees to overcome their particular problems, help them to enhance their competency, allowing employee to decide and address their needs, facilitate training, empower employee in the decision making and promote rewarding system.

Ahmed \& Malik (2019) displayed on their study a significant finding that psychological empowerment and job performance is positively and significantly mediate by psychological well. This result confirmed that teachers with higher performance have the characteristic of self-determination, competence on their job, feel that they have meaningful job and feel impactful toward the result of their students achievement.

Considering the importance of teacher empowerment, this study propose hypothesis as follow

$\mathrm{H} 1$ : Empowerment is positively related to job performance

\section{Self-Regulation}

Self-regulation have been identified in four general assumption, namely: First, the optimization of "assumption that is highly constructive" that comes from the cognitive aspect. This viewpoint is expected to arise as individuals define their own context, how they formulate goal as well as strategy in analysing information they receive from both of external and internal environment. Second, is the emergence of control assumption. This is the part when one can monitor, check and evaluate the dimension of their cognitive, motivation and behaviour (metacognition). Third, the criterion and goal or standard assumption. Individuals are expected to plan their own goal as their strategy to improve their own learning. This isan attempt how individuals regulateattributes they have to achieve those goals. The final assumption is the self-regulation activity in which act as a connector between both personal and contextual nature with achievement and performance (Pintrich, 2004). 
Zimmerman (2008) argued that several self-regulation techniques are proved to increase individuals performance in online learning. Previously, another research conducted by Zimmeman\&Martines-Pons concluded that highly successful students are proved applying more self-regulated strategies than their friends who are not implement the strategy. Considering that teacher profession has to deal with creativity and problem solving. It is critical for teacher to comprehend and implement the concept of SelfRegulation (Paris \& Winograd, 2013)

Furthermore, Paris and Winograd ,2013 believe that to create a successful teachers, one must be both analytical and reflective about their own practices moreover on their beliefs. They also need to have a deep understanding in the area of cognitive and motivational principle in learning and teaching. The result study of Gol \&Royaei, 2019 showcase a significant and strongrelationship between two variable of teachers' selfregulation to job performance. This finding align with empirical and theoretical studies that has been conducted previously.

Therefore the second hypothesis :

$\mathrm{H} 2$ :Self - Regulation is positively related to job performance

\section{Istiqomah}

Definition of Istiqamahcan be interpreted as standing upright strongly. The root word of istiqamahis from the Arabic word of "Qooma"that has a meaning "standing", while in etymology, istiqamahmeans has a meaning of being upright. Istiqamahidentified as having a strong stance of principle. The characteristics of an istiqamah is an individual with noble character and consistent attitude, has the ability to act in a manner conforming with principles, unshaken, held their principles and commitments strongly regardless the conflict of interest they may have encountered (Tasmara, 2002).

Istiqamahexpects someone to remain stand in their believe despite all obstacles. A part of Istiqamahis being consistent in which keep following the straight path though in times of hardship. Istiqamah goes beyond the philosophical belief, it is rather "a character that inherent in the soul of every Muslim who hold on tight the spirit of tauhid" (Tasmara, 2002). The value of istiqamahinclude a maximum effort of task completing followed by tawakkal(total surrender). Example of the implementation of istiqamahin management is when one company facing an issue, the employees are required to strive for the best result with maximum effort. Dinsi (2008) argued that tawakkalcorrelates to a fixed plan or willingness to sacrifice guided with optimum effort in implementing a plan.

Reseach conducted by Falikhatun\&Suparno(2015) in small and middle enterprise (UMKM) in Karanganyar, Central Java, Indonesia indicate that Istiqamah as apart of Islamic Work Ethic significantly affect employees welfare. This means the value of Istiqamah are applied in the human management setting. Correspond with that result, this research purposively intends to analyze the correlation between istiqamah and job performance. 
Therefore our hypothes is is:

$\mathrm{H} 3$ : Being Istiqomah is positively related to job performance

\section{Job Performance}

Performance of the employee is delivered when individual accomplished their purposive result, goals or level quality as how it is expected by the company. Appraisal of the employeeare measured on how well they fulfill their task in comparison to the performance requirementdesign by the organization. In other definition, it is the achievement of a required task to measure the standards that has been decided by the employer including the utilization of their resources, the use of time and energy, cost, initiative, problem solving skills, completeness, speed. (Bon, 2012).

Obilade (1999) in Amin et al (2013) argued that the description of teachers' job performance can be seen asan obligation delivered by the teacher in a specific time period within the school system in accomplishing goal of the organization. While Okeniyi (1995) in Amin et al (2013) stated that it represent as teachers' ability in enhancing the teaching and learning processes by utilizing all the combination of relevant inputs.

In non-formal education setting, teachershold a very important role in determining the success of the learning outcome and goals. Teachers are involved directly in teaching and learning activity with the students. The success of the learning outcome are align with the performance from the teacher. Therefore the improvement in the quality of the human capital must continuously improved (Muhammad \& Abubakar, 2018)

Teachers' performance can be measured based on the competency they acquired. It is particularly highlighted the pedagogic competency, teaching and learning process, disciplines, and interrelation with other member of the staff. Moreover, it is also evaluates the learning outcome of the teaching and studying (Muhammad \& Abubakar, 2018)

\section{RESEARCH METHOD}

\section{Participants}

Sixty six non-formal education teachers $(\mathrm{N}=66)$ participate in this study. The respondent consist of 51 female and 15 male. The participants are educators or teacher in nonformal education. Teachers agesspan from 22 years old to 54 years old. The experience of their teaching journey started from 1 to 9 years. The data collected is using google form and send to the administrator of the non-formal education.

\section{Research Design}

\section{Graphic 1}




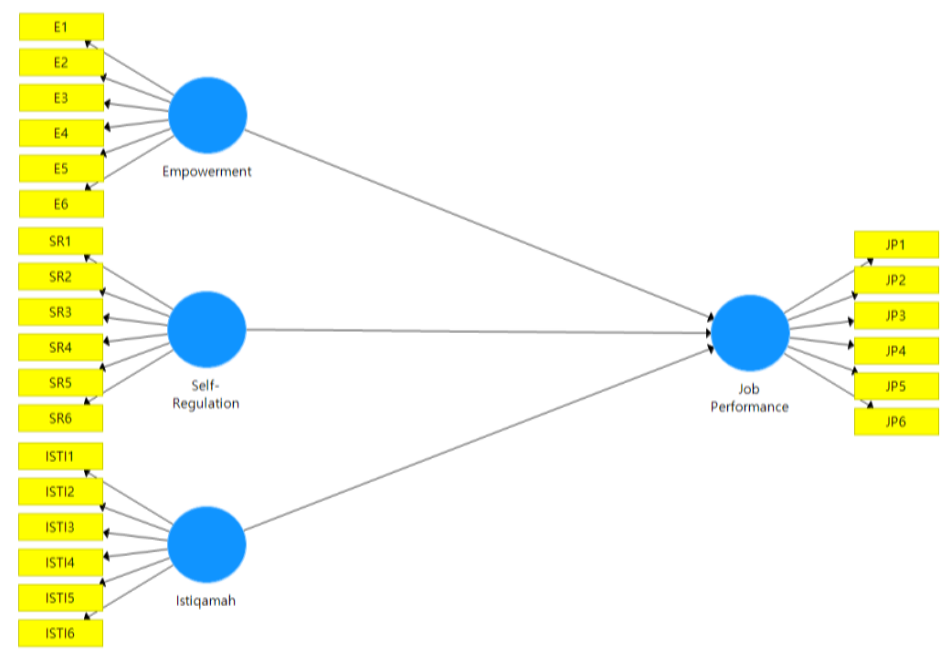

Source: Smart PLS version 3.0

\section{Instrument of the study}

The questionnaire consists of 24 questions dividedin 4 sections using 1-5 Likert scale.To measure Empowerment, this paper utilize the psychological empowerment scale used by Spreitzer (1995), To measure Self-Regulation, we useThe Self-Regulation Questionnaire (SRQ) (Brown, Miller, \&Lawendowski, 1999), Istiqomahis masuredby using Islamic work ethic scaling Ali (1988), The questionnaire Teachers' job performance self-rating questionnaire (TJPSQ) was developed to measure teachers' job performance.

\section{Data Analysis Techniques}

Data collected through survey questionnaire was analyzed by using Smart PLS version 3.0 after analyzing the descriptive statistics of sample, data reliability analysis determine. Moreover, to test the hypotheses, correlation test was utilized to evaluate the relationship between constructs as a preliminary support.

\section{B. RESULT AND DISCUSSION}

\section{Outer model testing}

Based on the calculation, the Average Variance Extracted indicated that each output are greater that 0.5. It concluded that the construct of empowerment, self-regulation, istiqamah and job performance demonstrated a good model and pass the criteria of discriminant validity

Table 1 
Construct Reliability and Validity

\begin{tabular}{|c|c|c|c|c|c|c|c|c|}
\hline \multirow[t]{2}{*}{ Matrix } & \multicolumn{2}{|c|}{ 掉基 Cronbach's Alpha } & 掉筷 rho_A & \multicolumn{2}{|c|}{ 期辛 Composite Reliability } & \multicolumn{2}{|c|}{ 掉条 Average Variance Extracted (AVE) } & \\
\hline & \multicolumn{3}{|c|}{ Cronbach's Alpha } & rho_A & \multicolumn{2}{|c|}{ Composite Reliability } & \multicolumn{2}{|l|}{ Average Variance Extracted (AVE) } \\
\hline \multicolumn{2}{|c|}{ Empowerment } & & 0.819 & \multicolumn{2}{|l|}{0.830} & 0.880 & \multicolumn{2}{|c|}{0.649} \\
\hline \multicolumn{2}{|l|}{ Istiqamah } & & 0.825 & 0.839 & \multicolumn{2}{|c|}{0.875} & \multicolumn{2}{|c|}{0.584} \\
\hline \multicolumn{2}{|c|}{ Job Performance } & & 0.830 & 0.856 & \multicolumn{2}{|c|}{0.886} & \multicolumn{2}{|c|}{0.663} \\
\hline \multicolumn{2}{|c|}{ Self-Regulation } & & 0.777 & 0.781 & \multicolumn{2}{|c|}{0.857} & \multicolumn{2}{|c|}{0.601} \\
\hline
\end{tabular}

Source: Smart PLS version 3.0

Based on the table above, it is demonstrated that the composite reliability value for the empowerment variable is 0.880 , Istiqamah 0.875 , self-regulation 0.857 and job performance 0.886. All the variables have Cronbach alpha more than 0.7, It can be described that the research model and instrument have met the construct reliability and validity.

\section{Inner model}

The inner model evaluate andutilizes R-square (R2) for the construct dependent. The Rsquare value indicate the significance of the predictive power in the variable. With of the requirement of the R-square valueis greater than 0.10 as goodness-fit of the model. Basedon the PLS as the data processor, R-squareis resulted as stated in table 2 :

Table 2

\begin{tabular}{|c|c|c|c|c|c|c|c|}
\hline \multirow[t]{2}{*}{ 国 Matrix } & 揕虽 Path Coefficients & & & & Copy to Clipboard: & Excel Format & R Format \\
\hline & Empowerment & Istiqamah & Job performance & Self-regulation & & & \\
\hline \multicolumn{2}{|l|}{ Empower... } & & 0.274 & & & & \\
\hline \multicolumn{2}{|l|}{ Istiqamah } & & 0.453 & & & & \\
\hline \multicolumn{5}{|l|}{ Job perfo... } & & & \\
\hline \multicolumn{2}{|l|}{ Self-regul... } & & 0.157 & & & & \\
\hline
\end{tabular}

Source: Smart PLS version 3.0

Based on table 2, it can be seen that the R-square for the Empowerment is 0.274 whichindicates that the job performance influenced by Empowerment is $27.4 \%$. The R-square value for the Self-regulation variable is 0.157 which means that job performance influenced by Self-regulation is $15.7 \%$. While the R-square value ofistiqamah is 0.453 depicting that job performance influence by that variable is 45 .

\section{Graphic 2}




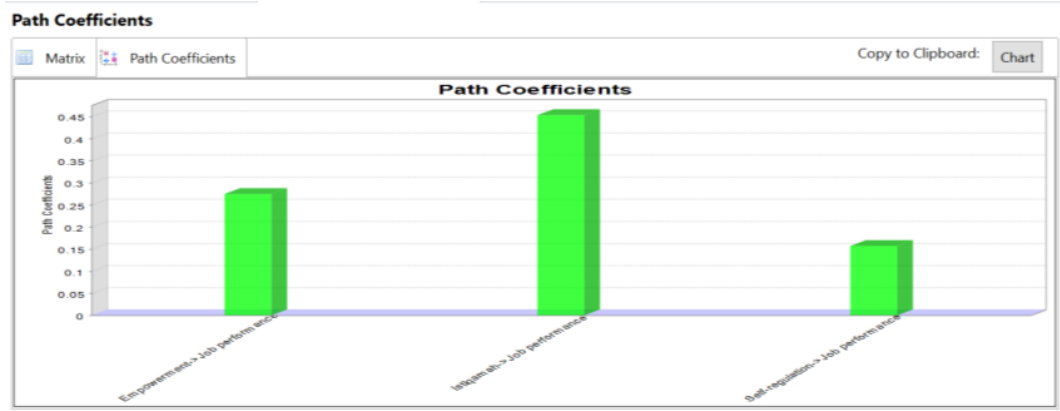

Source: Smart PLS version 3.0

Graphic 3 visualized the contribution of the independent variable, namely empowerment, istiqamah and self-regulation in constructing teachers' performance.

\section{Graphic 3}



Source: Smart PLS version 3.0

Graphic 3 depicted the adjustment made during the analysis using smart pls version 3 to generate the model that meet the assumption of validity and reliability. It is also readjusted to identify which instrument require a further improvement.

The result of the R-square value demonstrated the intensity of all independent variable in explaining or constructing the dependent variable. The higherthe predictive relevance, the better the model, and qualifyuse for further research.

\section{Table 3}




\begin{tabular}{|c|c|c|c|c|c|c|}
\hline \multirow[t]{2}{*}{ 圊 } & \multirow[t]{2}{*}{ Matrix } & \multirow[t]{2}{*}{ 期章 R Square } & \multirow[t]{2}{*}{ 模萃 } & \multicolumn{2}{|c|}{ R Square Adjusted } & \\
\hline & & & & R Square & \multicolumn{2}{|c|}{ R Square Adjusted } \\
\hline Job & Perforn & lance & & 0.547 & & 0.525 \\
\hline
\end{tabular}

Source: Smart PLS version 3.0

The table above demonstrate that empowerment, istiqamah and self-regulation have the power to explain job performance as big as $54.7 \%$. While $45.3 \%$ are determine by other variables.

\section{Table 4}

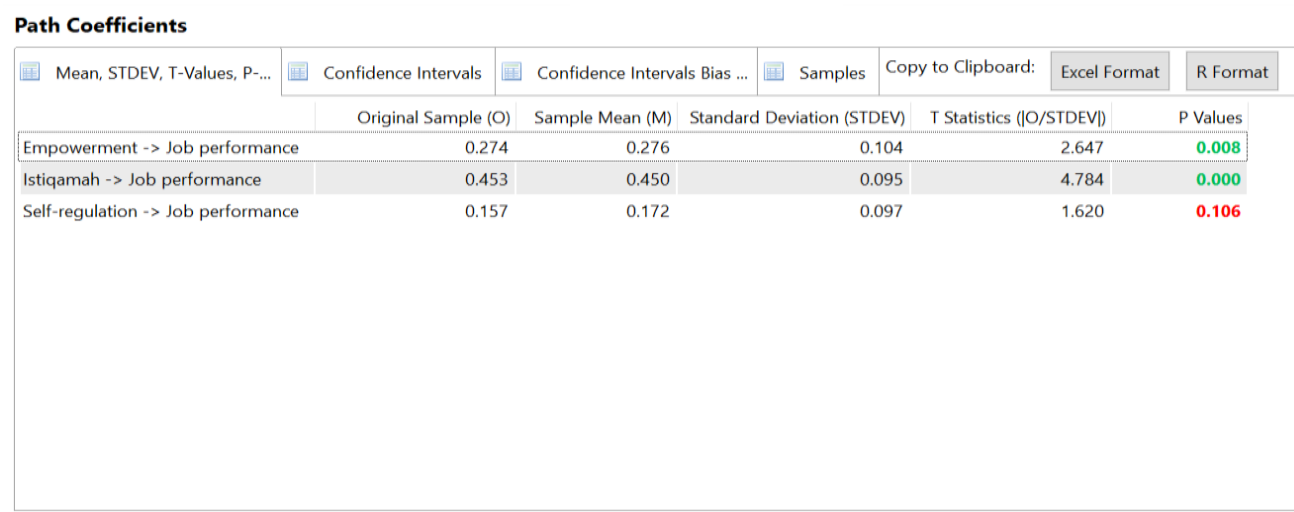

Source: Smart PLS version 3.0

Table 4 exhibit that both empowerment and istiqamah have a positive and significant effect on teachers' performance. In the meantime, variable self-regulation proved to have no relation nor significant effect on the performance of non-formal education teachers.

\section{CONCLUSION}

The results of this study conclude that empowerment and being istiqamah affect positively teachers' performance in non-formal education setting. While self-regulation proved to be insignificant and not influence the job performance. This result has difference with previous study whereas all three variables determine positively the outcome of the job performance. This study has attempt to use variable istiqamah in educational field and outstandingly illustrate the highest variable with significant effect on teachers' performance in non-formal education setting.

\section{Limitations and Future Direction}

This study focused only non-formal education teachers around Jakarta, whereas, expanding the concerned study toteachers'non-formal education with wider range will 
provide more accurate and solid results. Moreover, this study was a cross-sectional study. A longitudinal study will show the long-term effects of psychological empowerment, istiqamah and self-regulation on the performance of teachers. Further, the data collected, was based on self-reporting method. In addition, the data was collected only from limited area.

\section{Daftar Pusaka}

Ahmed, N., \& Malik, B. (2019). Impact of Psychological Empowerment on Job Performance of Teachers: Mediating Role of Psychological Well-being. Review of Economics and Development Studies, 5(3). doi: 10.26710/reads.v5i3.693.

Ali, A. (1988). Scaling an Islamic Work Ethic. The Journal of Social Psychology, 128(5), 575-583. doi: 10.1080/00224545.1988.9922911.

Amin, M., Shah, R. U., Ayaz, M., \& Atta, M. A. (n.d.). TEACHERS' JOB PERFORMANCE AT SECONDARY LEVEL IN KHYBER PAKHYUNKHWA, PAKISTAN . Gomal University Journal of Research, 29.

Arslan, M., \& Zaman, R. (2014). Effect of Empowerment on Job Performance: A Study of Software Sector of Pakistan . Research on Humanities and Social Sciences, 4.

Asiyai, R. I. (2018). Exploring The Contributions Of Non-Formal Education To The Development Of Human Capital In Southern Nigeria. Sokoto Educational Review, 18(1), 11. doi: 10.35386/ser.v18i1.49

Asiyai, R. I. (2018). Exploring The Contributions Of Non-Formal Education To The Development Of Human Capital In Southern Nigeria. Sokoto Educational Review, 18(1), 11. doi: 10.35386/ser.v18i1.49

Baswedan, A. (2014) GawatDarurat Pendidikan Indonesia

Brown, J. M., Miller, W. R., \&Lawendowski, L. A. (1999). The Self-Regulation Questionnaire. In L. VandeCreek\& T. L. Jackson (Eds.), Innovations in clinical practice: A source book (Vol. 17, pp. 281-289). Sarasota, FL: Professional Resource Press.

Degago, E. (2014). A Study on Impact of Psychological Empowerment on Employee Performance in Small and Medium Scale Enterprise Sectors . European Journal of Business and Management, 6(27).

Dinsi, Valentino, \& Abe, D. (n.d.). Secrets: Eight Secrets of Achieving Happiness in the World and Hereafter. Jakarta, 2008: Let's Go Indonesia. 
Gol, A. K., \&Royaei, N. (2013). EFL Teachers Self-regulation and Job Performance. Theory and Practice in Language Studies, 3(10). doi: 10.4304/tpls.3.10.1855-1861

Muhammad, A. S., \& Abubakar, A. (2019). Development of Early Childhood Education Teachers in the Teaching and Learning Process by Inspectors in an Attempt of Improving Teacher Performance. Proceedings of the 2nd International Conference on Research of Educational Administration and Management (ICREAM 2018). doi: 10.2991/icream-18.2019.15

Mustafa, E., \& Bon, A. T. (n.d.). Role of Employee Empowerment in Organization Performance: A Review. Research Journal of Social Science \& Management (RJSSM), 2(6), 79-83.

Obilade, S.O (1999) Leadership Qualities and Styles As They Relate to InstructionalProductivity. The Manager Ibadan:Department of Educational Management University of Ibadan

Ololube, nwachukwu prince. (2011). Education and society: An interactive approach

Ololube, N. P. (n.d.). 71 International Journal of Scientific Res A Critical Assessment of the Role/Importance of Non-Formal Education to Human and National Development in Nigeria: Future Trends . International Journal of Scientific Research in Education, 5(2).

Okeniyi, C.M (1995) Relationship Between Leadership Problems and School Performance in Oyo State Secondary Schools. Unpublished. M.ed. Thesis University of Ibadan.

Paris, S. G., \&winograd, P. (2003). The Role of Self-regulation Learning in Contextual Teaching: Principles and Practices for Teacher Preparation. A Commissioned Paper for the U.S. Department of Education Project Preparing Teachers to Use Contextual Teaching and Learning Strategies To Improve Student Success In and Beyond School.

Pintrich, P. R. (2004). A Conceptual Framework for Assessing Motivation and SelfRegulated Learning in College Students. Educational Psychology Review, 16(4), 385407. doi: 10.1007/s10648-004-0006-x

Spreitzer, G. M. (1995). Psychological, Empowerment In The Workplace: Dimensions, Measurement And Validation. Academy of Management Journal,38(5), 1442-1465. doi: $10.2307 / 256865$

Sudarsana, I. $\quad$ K. (2016). PeningkatanMutu Pendidikan LuarSekolahDalamUpayapembangunanSumberDayaManusia. JurnalPenjaminanMutu, 1(1), 1. doi: 10.25078/jpm.v1i1.34

Tabacaru, C. D. U. M. I. T. R. U. (2018). Impact Of Non-Formal Education On The Efficacy Of School Learning. ST U D I A U N I VER I T A T I S M OLDAVIAE, 229-233. 
Toto, T. (2002). Develop the Islamic Work Ethics. Jakarta: GemaInsani.

Ukwuaba, L. C. (2015). Enhancing Healthful Living Practices Among Rural Women in Nigeria through Non-Formal Education. International Journal of Technology and Inclusive Education, 4(1). doi: 10.20533/ijtie.2047.0533.2015.0068.

Zimmerman, B. J., \& Martinez-Pons, M. (1990). Student differences in self-regulated learning: Relating grade, sex, and giftedness to self-efficacy and strategy use. Journal of Educational Psychology, 82(1), 51-59. doi: 10.1037/0022-0663.82.1.51

Zimmerman, B. J. (2008). Investigating Self-Regulation and Motivation: Historical Background, Methodological Developments, and Future Prospects. American Educational Research Journal, 45(1), 166-183. doi: 10.3102/0002831207312909 